International Labor and Working Class History

Number 20, Fall 1981, p. 72

\title{
The Lowell Conference on Industrial History
}

\section{Susan Porter Benson}

\author{
Bristol Community College
}

The Lowell Conference on Industrial History was held at the University of Lowell on May 21 and 22, 1981. Sponsored by the Lowell National Historical Park, the conference had as its theme "The Relationship of Government and Industry in the United States." Carl E. Prince spoke on "Daniel Webster, the Boston Associates, and Government's Role in the Industrializing Process, 1815-1830," pointing out the ways in which federal preferment obtained through Webster contributed to the expansion of the New England textile industry. Peter Temin and Gerald D. Nash presented overviews of the government-business relationship in, respectively, the nineteenth century and the period since 1940. Of most interest to labor historians was David Montgomery's " 'Liberty and Union': Workers and Government in America, 1900-1940." He emphasized the crucial link between collective bargaining and civil liberties in this era, discussing the relentless repression of labor activists by government at all levels. Some relief from this pressure came in the late 1930's through a combination of worker militancy, the Wagner Act, some pro-labor Supreme Court decisions, and local political revolts. A final panel discussion brought together Stuart Bruchey, Montgomery, Nash, and Prince, to consider questions raised by moderator Thomas Dublin about the role of law in the American economic order.

The conference also included a tour of Lowell, films about the city and its history, and a reception marking the completion of the restoration of Memorial Hall in the city's Public Library.

The audience included labor historians, economic historians, and business historians, and the conference provided a forum for a stimulating interchange among the three groups. 